\title{
The Rights of the Children Who Conduct Ngenger in Javanese Society
}

\author{
Arinto Nugroho* \\ Department of Law, Faculty of Social \\ Sciences and Law \\ Universitas Negeri Surabaya \\ Surabaya, Indonesia \\ arintonugroho@unesa.ac.id
}

\author{
Budi Hermono \\ Department of Law, Faculty of Social \\ Sciences and Law \\ Universitas Negeri Surabaya \\ Surabaya, Indonesia \\ budihermono@unesa.ac.id
}

\author{
Irfa Ronaboyd \\ Department of Law, Faculty of Social \\ Sciences and Law \\ Universitas Negeri Surabaya \\ Surabaya, Indonesia \\ irfaronaboyd@unesa.ac.id
}

\begin{abstract}
In Javanese society, especially in Central Java and the Special Region of Yogyakarta, there is a culture named Ngenger, which means joining people who are richer, more powerful, more respectable or smarter than their own family. Children who conduct ngenger have to perform various tasks ordered by the host in exchange for which, generally, are not money but are food, livestock or school fees. The problem is, from a legal perspective, the relationship between a child who conducts ngenger to the host is similar to a work relationship that creates rights and obligations on the parties. This research discusses the rights that should be obtained by children who conduct ngenger. The results showed that the relationship between the child conduct ngenger to the host is a work relationship. In this way, a child who conducts ngenger can be classified as a worker. This is because the elements of the work relationship are fulfilled namely the existence of work, orders, wages, and time. As the children who conduct ngenger is a worker, the have the right to get a decent wage, the right to get appropriate working time, the right to get adequate rest and leave, the right to education and the right to get safety and health in working.
\end{abstract}

\section{Keywords: Rights, Children, Ngenger, Javanese}

\section{INTRODUCTION}

the majority ethnic group with a percentage of $41 \%$ of the total population in Indonesia [1]. Apart from the majority, the Javanese also have a variety of cultures, one of them is ngenger. Etymologically, Ngenger means "to serve."[2]. It is further explained that ngenger is joining other people in an effort to gain knowledge, experience and skills for future life. As explained by Moertono, ngenger is generally performed by children between the ages of twelve and fifteen. In his writing he explains that: "as a boy aged twelve to fiveteen he has to serve in one family, usually the one with a higher position. He may do the work that servants usually do such as sweeping the floor or fetching water, but in essence serving is learning life by experiencing the humiliations and difficulties that exist in a lower position and secondly learning by observing manners in a higher "environment"[3]. Based on the description above, it can be seen that according to Javanese philosophy, ngenge

$r$ is an educational concept that is pursued by a person by following and serving others.

In carrying out daily work, children who conduct ngenger are usually asked to do domestic work such as sweeping floors, feeding livestock, caring for the house and so on without receiving monetary compensation. In a book published by the International Labor Organization, it is stated that "usually child domestic workers who are still closely related even though they work to help with jobs like domestic servants, they are still treated as relatives and are not paid - in Javanese terms, they are categorized as "ngenger"[4]. Children who conduct ngenger must fully understand they always thave to be ready for work. The host will generally convey a series of routine work to be done. In addition, the children who conduct ngenger must always be ready for work that comes outside of his routine. This is possible because in general, children conduct ngenger stay at the house of the host. In this view, the culture of ngenger is seen as a positive thing considering ngenger, although the process seems to be unpleasant, turns out as a means to make children more mature, independent and have life skills in the future.

On the other hand, the relationship that occurs between children who conduct ngenger and the host can be viewed as a working relationship. This is because the child is carrying out a job ordered by the host. It's just that he doesn't get a reward in the form of money but more on basic needs in the form of food and life experiences. This is in accordance with the definition of a worker according to Article 1 point 3 of Law Number 13 Year 2003 concerning Manpower, namely "A worker / laborer is any person who works and receives wages or other forms of remuneration". If categorized as a working relationship, the rights and obligations of each party will naturally arise. Apart from the rights as workers, the status of the child who is a worker also has 
special rights that must be considered by the host. There are a number of laws and regulations that form the basis of regulating child labor from international to national levels.

The phenomenon of ngenger which is commonly practiced by Javanese people and is considered positive in order to provide life skills and experiences for children in the future, while on the other hand there are rules that provide protection for children made the researchers interested to study deeper. Based on the above problems, the purposes of this study are to determine whether the children who conduct ngenger can be categorized as a worker and what is the right of the children who conduct ngenger.

\section{RESEARCH METHODS}

In conducting this study, the researcher uses normative legal research which is "concerned with the formulation of legal 'doctrines' through the analysis of legal rules"[5]. The normative legal research uses secondary sources of law or materials obtained from library materials.[6] Based on the above explanation, the research is conducted by looking at library materials related to research objects such as norms or rules[7]. This study will then analyze the phenomenon of ngenger from the legal perspective.

This research uses a prescriptive analysis technique, "a technique which is intended to provide the arguments. The argument used to consider whether an action is correct or incorrect and/or what should it be based on the law". Furthermore, this research uses "statute approach in which the researcher uses regulation as the basis to analyze the data".[8]

The main sources to understasd the positive law used in this paper is in the form of primary and secondary sources.

\section{a. Primary sources of Law}

Primary sources of law are authoritative which mean the sources of law have the authority, which is the product of institution's activities. Primary sources of law here are norms or basic principles of law in Indonesia and some regulations that are relevant to this study, namely:

1. Indonesian Constitution;

2. Indonesian Civil Code;

3. Law Number 29 Year 1999 Concerning Human Right

4. Law Number 23 Year 2002 Concerning Child Protection

5. Law Number 13 Year 2003 Concerning Manpower;

\section{b. Secondary Sources of law}

The secondary sources of law are the materials which are related to the primary sources of law. These will help explain and understand the primary sources of law. The secondary sources of law in this study are papers, journals, articles and news, the results of legal research, legal dictionary and encyclopedia of law relevant to this study, either printed or online.

\section{RESULT AND DISCUSSION}

Based on the research problems, this section will be divided into 2 parts, namely: The children who conduct ngenger can be categorized as workers and the rights of the children who conduct ngenger..

\section{A. The children who conduct ngenger can be categorized as workers}

The culture of ngenger in Javanese society has been going on for a long time, although there are not many, there are still some who do so. The International Labor Organization defines ngenger as "a tradition known in Javanese society, which means that a child from an underprivileged family is entrusted to a relative or extended family in a city who is considered more established or can also be entrusted to a family that does not have any family ties but has a commitment. to help the child. Ngenger's goal is for children to be covered with all their living costs and education for a better future. In return, the child has to help with various household chores."[4] while the definition of child can be found in various laws and regulations relating to children. According to Article 330 of the Civil Code, children are those who have not reached the age of 21 years and have not previously married.[9]. Meanwhile, according to Article 47 of Law Number 1 Year 1974 concerning Marriage, Article 1 number 26 of Law Number 13 Year 2003 and Article 1 paragraph (4) of Law Number 44 Year 2008 concerning Pornography, what is meant by children are those who have not reached 18 years old.

Children who conduct ngenger to other people's families generally come from families that are economically and socially lower than other families. Degrees and ranks [lay important role in the social structure of Javanese society because power is a very valuable thing. This belief has become a myth from generation to generation that is described by the Javanese people. Belief in these myths which then stimulates the public to achieve these degrees and ranks. In the myth, various ways are always mentioned how to get that degree and rank. One way that is known is by "ngenger".

The problem is that, children who conduct ngenger generally do jobs that are usually done by adults. Several types of work performed by children who conduct ngenger are cleaning the house, caring for livestock, maintaining home security, and several other jobs that are not related to the interests and talents of the child. Morover, the jobs also have risks related to the safety and health of the child. According to Indonesian law, children have the rights and obligations. Children's rights are clearly stipulated in Article 28B paragraph (2) of the Indonesian Constitution, namely the right to live, grow, develop and receive protection from violence and discrimination. With regard to children's rights to get protection from violence and discrimination, it is further elaborated in Article 13 paragraph (1) of Law Number 23 Year 2002 which states that every child who is in the care of a parent, guardian, or any other party who is responsible for care, entitled to protection from discriminatory treatment; exploitation, both economic and 
sexual; neglect; cruelty, violence and persecution; injustice; and other mistreatment. Other mistreatment, for example, is abuse and indecent acts against children. Furthermore, according to Article 14 of Law Number 23 Year 2002, separation of children from their parents can only be carried out if there is a legal rule which shows that the separation is in the best interests of the child and is the last consideration.

More specific regulations regarding working children can be found in Law Number 13 Year 2003. People who work for other parties are bound by a work relationship. The working relationship creates rights and obligations between the parties. Article 1 point 14 of Law Number 13 Year 2003 concerning Manpower explains that "An employment relationship is a relationship between an entrepreneur and a worker / laborer based on a work agreement, which has elements of employment, wages and orders."

Based on the provisions above, the elements of the work agreement in accordance with the provisions of the article are:

1. The existence of work

2. There are orders

3. There is a wage

4. There is a certain time limit (can be indefinite / retirement based on a certain time)[10]x

The first element of a work relationship is the existence of work. The children who conduct ngenger have an obligation to work for the Host. This work can be in the form of household chores, or many others. They will be fully bound to the task ordered by the Host. The second element is the existence of an order, in the relationship between the children who conduct ngenger to the host, it can be analogized that the host is the employer and the child children are the workers.

The third element is wages. Wages are defined as remuneration given by the employer for work that has been done by the employee. The work done by the the children who conduct ngenger is not paid in cash by the host, but he/she has an obligation to cover all the necessities. The fourth element is having a time limit (can be indefinite / retirement based on a certain time). The relationship between the children who conduct ngenger to the host generally ends when the children is already "mentas", meaning that the child is married.

The description above explains that the elements of the work relationship between the the children who conduct ngenger to the host have been fulfilled, but the relationship has a difference, namely the absence of a written work agreement. However, regulations in Indonesia also do not recquire work agreements must be in written form. The valid terms of the agreement according to Article 1320 of the Civil Code are:

1. There is an agreement for those who bind themselves;

2. The ability of the parties to make an agreement;

3. A certain thing; and

4. A halal causa.

This article is then adopted by Law Number 13 Year 2003 concerning Manpower in Article 52 that mentions the terms of the Work Agreement are::

a. Both side agreement; b. The ability to take legal actions;

c. The is a work; and

d. The promised work is not against the order, decency, and the prevailing laws and regulations.

All and all, based on the description that has been given, it is very clear that children who conduct ngenger to their host when viewed from the Manpower Law are categorized as workers and therefore have rights as child labor

\section{$B$. The rights of the children who conduct ngenger}

Children's rights are part of human rights that must be guaranteed, protected and fulfilled by parents, family, community, state, government and local governments (Article 1 paragraph (12) of Law Number 35 Year 2014). Children, who in this case, are those who conduct ngenger, like adults, have the right to basic human rights. However, because of their needs, children's rights need special attention and treatment. There is a Convention on the Rights of the Child which is an international legal instrument designed to uphold and protect children's rights. The rights of the child include: (1) the right to survival, (2) the right to grow and develop, (3) the right to be protected, and (4) the right to participate. In this corridor, it is not justified to act against children that can hinder their growth and development. A child who cannot be properly cared for by his parents can result in the cancellation of parental custody.

Children who conduct ngenger are included in the category of child labor. In this regard, the rights possessed by children are as stipulated in Law Number 39 of 1999 to Law Number 35 of 2014 which is summarized as follows:

a. The right of Life

Children have the right of live as referred to in Article 53 Paragraph (1), namely "Every child since the womb, has the right to live, maintain life and improve his standard of life". This guarantees the child that all parties are obliged to make efforts so that the child can live starting from the womb with all the best efforts

b. The right of Education

Article 60 Paragraph (1) states that "Every child has the right to receive education and teaching in the framework of personal development according to his interests, talents and level of intelligence". Currently, the paradigm for sending children to school is very advanced, but if we look back a few decades ago, the provision of opportunities for schooling to children was not too high so the children who conducted ngenger generally did not have proper education. Graduating from elementary school and not continuing to junior high school was something that was common at that time.

c. The right of not to be separated from parents, Furthermore, children also have the right not to be separated from their parents as regulated in Article 59 Paragraph (1), namely "Every child has the right not to be separated from his parents against the child's own will, unless there are valid reasons and legal rules which indicate that separation is in the 
best interests of the child. In ngenger culture, the right not to be separated is ignored because children generally are separated from their parents, even temporarily, because they live in the host's house.

d. The right of health service,

Every child has the right to get proper health services and social security, according to their physical and mental and spiritual needs. This is regulated in Article 62 which means that the person caring for the child has the obligation to ensure the child's health with the best possible effort. In the context of the children who conduct ngenger, health insurance by the social security program is something that is rarely found.

e. The right to be free from economicexploitation As for the right not to be exploited economically, Article 64 explains that "Every child has the right to receive protection from economic exploitation activities and any work that endangers him, so that it can interfere with his education, physical health, morals, social life, and mental spirituality. This is a contradiction with the reality that society considers ngenger activities to be more about dedication that will benefit children for the future, while on the other hand, children who conduct ngenger generally come from underprivileged families and hopefully by living and doing various jobs for the host. it will reduce the burden of the children family

Apart from the rights described above, there are also other rights that should be obtained by child workers as stipulated in Law Number 13 of 2003 concerning Manpower, which includes:

a. The right to a decent work

Child workers / laborers must receive a wage in accordance with the prevailing laws and regulations, so that employers are prohibited from paying lower than the minimum wage stipulated by the local government as stipulated in Article 90 paragraph (1) of Law Number 13 Year 2003. If an employer promises to pay a wage lower than the minimum wage, then the agreement is null and void by law as stipulated in Article 91 paragraph (2) of Law Number 13 Year 2003. In relation to the children who conduct ngenger, this right is definitely neglected considering that The remuneration given is generally not in the form of money, but facilities including a place to live and in some cases livestock and is not given routinely in a certain period. It is quite difficult to convert the value of each thing, especially the one which is abstract

b. The rigt to get suitable working time

Article 69 in Law Number 13 of 2003 has provided exemption provisions that allow children who are 13 to 15 years old, to work in not more than 3 hours. Furthermore, it has to be done during the day, does not interfere with school time, there is written permission from parents or guardian, there is a work agreement with the parent or guardian, and is paid a wage according to the statutory regulations. If an employer violates Article 69 in Law Number 13 Year 2003, he will be subject to criminal sanctions as stipulated in Article 185.The right to get appropriate working time for a child who is ngenger is also difficult to realize considering that he lives with the host and must be ready at all times. to carry out work at the time the host gives orders.

c. The right to get adequate rest and leave

Article 79 paragraph (1) explaines that Employers are obliged to give workers / laborers a period of rest and leave. Apart from that, each worker is obliged to receive at least 12 days of annual leave, but under these conditions the worker must have worked for at least 1 year or 12 months in a company. In Article 79 paragraph (2) in Law Number 13 Year 2003 concerning manpower, workers who are entitled to 12 days of annual leave are workers who have worked for a minimum of 1 year in the company. In the context of children who conduct ngenger, the right to get a rest period is generally not specifically regulated. In principle, the child will be with the host every day so that the relationship is considered part of the family. therefore the term leave is not known.

d. The right of education

According to Article 9 of Law Number 35 Year 2014 concerning Amendments to Law Number 23 Year 2002 concerning Child Protection, it is explained that every child has the right to education and teaching in the context of personal development and the level of intelligence according to their interests and talents. In addition, every child is also entitled to protection in the education unit from sexual crimes and violence committed by educators, educational staff, fellow students, and / or other parties. Morover, Article 69 paragraph (2) letter d of Law Number 13 Year 2003 also explains that entrepreneurs who employ children in light work must be done during the day and do not interfere with school time. In relation to children who conduct ngenger, as explained in the previous section, the host paradigm about education in ancient times was not to good so that the granting of rights to children who conduct ngenger was also neglected.

e. The right to get safe and healthy working environment

Based on Law Number 13 year 2003, it has been regulated on all matters relating to employment ranging from working wages, working hours, maternal rights, leave to work safety and health. Based on Article 74 in this law, it is clearly stated that anyone is prohibited from employing and involving children in the worst jobs that can endanger the health, safety, or morals of the child. Concerning the children who conduct ngenger, it is 
very difficult to implement as the employer is a family which is certainly not as open as a company. This fact makes the potential for violations of the rights to child labor safety and health is high

The rights of child workers must be fulfilled by the employer and if the consequences are violated the employer will be sanctioned. This is very important considering that the subject of this discussion is children who are future assets and on the other hand have low bargaining power against employers. That is why the the existence of the state to protect children's rights is absolutely necessary

\section{CONCLUSION}

Based on the results of the study, it can be concluded that children who conduct ngenger to their hosts in Javanese society are considered something normal and there is nothing wrong with this, but when viewed from a legal point of view, the relationship between children who conduct ngenger to their hosts is a work relationship. In this way, they are qualified as workers. This is because the elements of the work relationship are fulfilled, namely the existence of work, orders, wages, and time. As they are child workers, their rights are to get a decent wage, the right to get appropriate working time, the right to get adequate rest and leave, the right to education and the right to get safe and healthy working environment.

\section{REFERENCES}

[1] Pemerintah Republik Indonesia, "Suku Bangsa," 2017. [Online]. Available: https://indonesia.go.id/profil/sukubangsa\#: :text=Indonesia memiliki lebih dari 300,mencapai $41 \% 25$ dari total populasi. [Accessed: 05-Mar-2020].

[2] Prawiroatmojo, Bausastra Jawa-Indonesia Jilid I. Jakarta: Gunung Agung, 1981.

[3] S. Moertono, Negara dan Usaha Bina-Negara di Jawa Masa Lampau: Studi tentang Masa Mataram II Abad XVI Sampai XIX. Jakarta: Yayasan Obor Indonesia, 1985.

[4] International Labour Organisation, “ Bunga-bunga di atas padas: fenomena pekerja rumah tangga anak di Indonesia. Jakarta: Kantor Perburuhan Internasional, 2004.

[5] P. Chynoweth, "Legal Research," in Advanced Research Methods in the Built Environment, 2008, pp. 27-38.

[6] I. J. Kroeze, "Legal Research Methodology and the Dream of Interdisciplinarity.," Potchefstroom Electron. Law J., vol. 16, no. 3, pp. 35-65, 2013.

[7] P. Langbroek, K. Van Den Bos, M. S. Thomas, M. Milo, and W. Van Rossum, "Methodology of Legal Research : Challenges and Opportunities," Utr. Law Rev., vol. 13, no. 3, pp. 1-8, 2017.

[8] P. M. Marzuki, Penelitian Hukum, 11th ed. Jakarta: Kencana, 2011.

[9] Subekti and Tjitrosudibio, Kitab Undang-Undang Hukum Perdata. Jakarta, Indonesia: Pradnya Paramitha, 1983.

[10] A. Wijayanti, Hukum Ketenagakerjaan pasca reformasi. Jakarta: Sinar Grafika, 2015. 